\title{
Editorial \\ Foreword to the thematic set on 'Melilitic, alkaline and calc-alkaline lamprophyric rocks. Centenary celebration of the first description of polzenites by K. H. Scheumann'
}

Coming to the north-eastern Bohemia in former Austro-Hungarian Empire in the year of 1907, Karl Hermann Scheumann was first as an artist amazed by picturesque landscape surrounding the town of Český Dub. Soon after he started with geological mapping and petrographic studies of this area, and was fascinated by a group of spectacular volcanic rocks forming a conspicuous dyke swarm. These were different from other known volcanic rocks in Central Europe and in the 1913, Karl Hermann Scheumann published his work proposing classification of these rocks that he named polzenites after Polzen, the German name for the Ploučnice River. The centenarian anniversary of the definition of polzenite was the right moment to commemorate Karl Hermann Scheumann and his work leaving an indelible trace in the classification of alkaline rocks.

Karl Hermann Scheumann was born on February $25^{\text {th }} 1881$ in Metz, a Lothringenian town which was then a part of Germany. His talent for drawing led to studies at the Kunstakademie (Academy of Fine Arts) in Dresden, where he spent his youth. His friends and family probably expected carrier in art, but young Karl H. Scheumann decided to change the direction of his life and started to study Natural Sciences at the University of Leipzig and applied his talent for precise and realistic drawing there. In the early times of photographs, quality drawings of microscopic textures were highly needed. Similarly, well-drawn block-diagrams showing the shape and spatial distribution of geological bodies had no alternative until the time of computers with 3D graphics software. To come to the Ploučnice Region in north-eastern Bohemia, he was motivated by his Professor R. Reinisch. He completed his field work comprising mapping of Cretaceous sediments and numerous volcanic bodies during several visits in 1907-1910. Before publishing his dissertation "Petrographische Untersuchungen an Gesteinen des Polzengebietes in Nord-Böhmen" in 1913 (Scheumann 1913), he spent additional two years by laboratory research. Inter arma silent Musae and therefore developments in science were interrupted by the forthcoming World War I. After the war, in which Karl H. Scheumann served as an infantryman, he started to compare the rocks from the Ploučnice region with similar suites from Alnö, Swabian Alb (Swabian Alps) and Kaiserstuhl (Scheumann 1922). After his habilitation in 1924 he was appointed to teach petrography at the University of Gießen, from where he moved to the University of Berlin in 1926. In 1928 he obtained a professorship in mineralogy and petrology and became a head of the Department of Petrography at the University of Leipzig. After the World War II and split-up of Germany into occupation zones, in 1946, Karl H. Scheumann was forced to move from the Soviet zone (subsequently separated as the GDR) to Bonn, where he played an active role in reconstruction and revival of the heavily damaged University. He was pensioned in 1951 and died in Bad Hersfeld (Hessen, central Germany) on April $28^{\text {th }}, 1964$.

More detailed biography of Karl H. Scheumann can be found in papers by O'Daniel (1951), Eigenfeld (1963) and Paluska et al. (2013).

It was the centenarian anniversary of the first definition of polzenitic rocks (Scheumann 1913) that motivated us to collect papers on lamprophyric rocks and compile this Special Issue of the Journal of Geosciences. It presents five contributions dealing with various aspects of lamprophyric magmatism and lamprophyric rocks in a broad sense from ultramafic to alkaline to calc-alkaline in nature.

Since the times of Scheumann, his classification of polzenitic rocks endured several times serious criticism and discussions, but serious revision based on original samples employing modern analytical methods was missing. This gap is filled with a paper by Ulrych et al. Their re-evaluation of the classification of this specific group of rocks is based on dataset of archive and new analyses of the rocks taken from original type localities of Karl Hermann Scheumann. The results underline the need of a special classification of polzenitic rocks. On the other hand, of the rocks defined by Scheumann, wesselite should be omitted from the polzenite group, as it belongs to common camptonites-monchiquites. Also geochronological data document that this wesselite was emplaced much later than Late Cretaceous/ Early Palaeocene polzenite and olivine melilitite dyke swarm.

Esteve et al. present the results of their investigation of camptonite sills from Platja Fonda in NE Spain (Catalonia). Very interesting is detailed description of field relations and discussion of possible emplacement mechanism for a cluster of thin lamprophyre sills presumably of Late Cretaceous age. Camptonites are of sodi-potassic to weakly potassic nature and, despite of their low mg-values, unusually low in silica. Authors discuss the origin of kaersutite 
and less abundant clinopyroxene macrocrysts and consider them phenocrysts, not antecrysts as has been proposed for other camptonite intrusions from the area. Briefly is discussed also the origin of parental magma batches from metasomatized mantle domains.

All remaining papers concentrate on calc-alkaline lamprophyres from various points of view. Contribution by Štemprok et al. is focused on relationships between the Variscan calc-alkaline lamprophyres and the Sn-W-Mo mineralization in the Eastern Krušné hory/Erzgebirge. The authors describe mineralogy and geochemistry of lamprophyres and pay special attention to their greisenized varieties rich in lithian phlogopite. The lamprophyric dykes intersected by greisen veins provided barriers favouring the cassiterite deposition.

Results of the LA-ICP MS U-Pb dating on zircons and monazites from vaugnerites (plutonic rocks equivalent in composition to K-rich calc-alkaline lamprophyres) and coeval granites of Variscan age from French Massif Central are presented by Couzinié et al. They interpret the large set of precise geochronological data in terms of long-range crustal anatexis leading to origin of migmatites but not granites. The production of voluminous granitic magmas was then triggered by heat input due to a sudden invasion of mantle-derived vaugneritic melts. The rapid heating and melting of the anatectic crust led to upward flow of partially molten rocks, doming and catastrophic collapse of the belt.

Paper by Krmiček et al. is focussed on the mineral/matrix partition coefficients for selected trace elements in a potassic mafic magma of calc-alkaline nature. This research has been performed using LA-ICP MS method combined with electron microprobe data for phlogopite and clinopyroxene phenocrysts set in an aphanitic matrix of a primitive Variscan minette dyke from the Železné hory Mts., eastern Bohemia. The authors consider their results applicable for a broader spectrum of calc-alkaline lamprophyric compositions.

Acknowledgements. We are grateful to all the authors who contributed to this volume, and to the referees who frequently handled the scientific and linguistic reviews under extremely tight schedule constraints.

\section{References}

Eigenfeld R (1963) Karl Hermann Scheumann zum 80. Geburtstag. Tschermaks Mineral Petrogr Mitt 8: 12

O’Daniel H (1951) Zum 70. Geburtstag Karl Hermann Scheumanns. Neu Jb Mineral, Abh 82: 5-6

Paluska A, Suhr P, Ulrych J, Fediuk F, Rapprich V (2013) Karl Hermann Scheumann, a geologist and petrologist in the area of the Czech-German border. In: Büchner J, RApprich V, Tietz O (eds) Basalt 2013. Cenozoic Magmatism in Central Europe, Abstracts and Excursion Guides, Czech Geological Survey, Prague \& Senckenberg Museum of Natural History, Görlitz, pp 234-235

Scheumann KH (1913) Petrographische Untersuchungen an Gesteinen des Polzengebietes in Nord-Böhmen. Abh kön Sächs Gesel Wiss math-phys K1 32: 607-776

Scheumann KH (1922) Zur Genese alkalisch-lamprophyrischen Ganggesteine. Zbl Mineral Geol Paläontol 2: 495-545

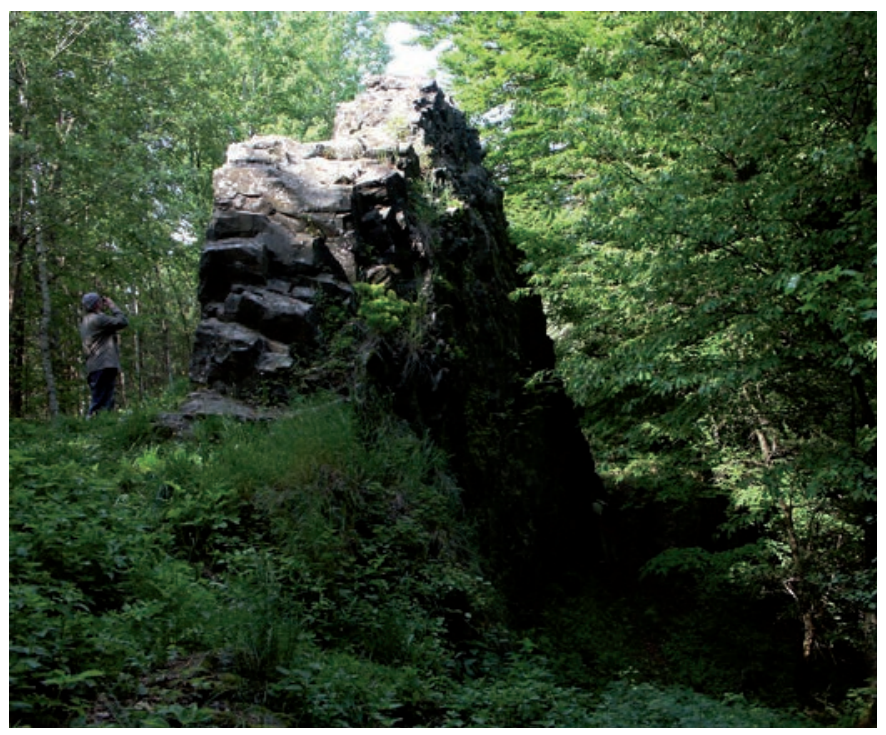

Vladislav Rapprich Czech Geological Survey, Prague, Czech Republic

František V. Holub Charles University, Prague, Czech Republic

[Guest Editors]

Remaining segment of the mostly excavated Devil's wall (olivine-melilite nephelinite) dyke. 